\title{
Government Expenditure and Sustainable Industrial Development in Nigeria
}

\author{
ALEXANDER EHIMARE OMANKHANLEN, PEACE ONYEDIKACHI CHIMEZIE, \\ LAWRENCE UCHENNA OKOYE \\ Department of Banking and Finance Covenant University, Ota, NIGERIA
}

Abstract: - The development of the industrial sector remains a contentious issue in Nigeria's economy.

This research examines the impact of Government expenditure on sustainable industrial development in Nigeria. The research adopted Johansen co-integration and vector error correction analysis via E- Views statistical software (version 10.0) for period between 1981 and 2018, to determine long-run impact of public finance on industrial growth in Nigeria. It used time series data extracted from CBN statistical bulletin (2018)

and WDI (2018). This research adopts Wagner's Law named after the German political economist Adolph Wagner (1835-1917), which best explains government expenditure and industrialization. This research study found out that government revenue is statistically insignificant but has a positive effect on industrial development; Manufacturing Value added as a proxy (MVA), a 100\% change in GREV will bring about 28\% changes in manufacturing output, capital expenditure is however statistically significant and negatively impacts industrial output, a change in CEXP will yield less than a proportional change in MVA by about 52\%, recurrent expenditure positively affects industrial growth, although its influence is statistically insignificant, a

$100 \%$ rise in REXP will cause about $41 \%$ increase in manufacturing sector's growth. Also, a change in capital

stock i.e. Gross Fixed Capital Formation (GFCF) will lead to a significant but inelastic and less than proportional change in MVA, thereby depicting inverse relationship. Based on the findings the following conclusions were made: Effective allocations of government revenue as well as the early release and approval of budget proposals will have a meaningful effect on the economy, increase in sustainable investment level alongside required equipment coupled with qualified personnel to properly manage these amenities will ensure improvement of the industrial sector and finally, working incentives in form of tax incentives, promotion and salary increment should be regularly encouraged in the industrial sector in Nigeria.

Keywords: government expenditure, industrial development, sustainability, Wagner's Law, Johansen co-integration

Received: August 5, 2020. Revised: December 1, 2020. Accepted: December 22, 2021. Published: January 7, 2021

\section{Introduction}

Industrialization without sustainability has known to cost the society in increasing inequality, poor living conditions and supposed scarcity of resources. Very few countries have been able to grow and accumulate wealth without Industrialization. Industrialization says; provide affordable products with minimal environmental degradation. Sustainable industrialization says; transform towards a desired vision of an industrialized economy, contributing to wealth creation, social development and environmental sustainability. The international community has taken a quantum leap over the last few years in pushing forward with innovative strategies to drive change and pave the way for a more sustainable, inclusive and universal development process beyond 2015. While industrialization was not factored into the framework of the Millennium Development Goals, inclusive and sustainable industrialization now features strongly in the Sustainable Development Agenda 2030. Goal number 9 states "Develop robust infrastructure, promote inclusive and sustainable industrialization and foster innovation" [22]. According to United Nations Industrial Development Organization (UNIDO) 2015 "Inclusive and sustainable development addresses all three dimensions of sustainable development, social equity, economic growth and environmental protection". 


\subsection{Statement of Research Problem}

Industrial development is imperative for socioeconomic progress of a state according to [9]. It creates productive employment, contributes to the accumulation of resources, technical advances and promotes economic development. Sustainable industrial development is characterized as improving living standards and reducing inequality, in particular through increase in the quantity and remuneration of jobs in the manufacturing sector.

Nigeria, like any emerging country, faces some obstacles in its rapid growth and attempts to boost its citizens ' quality of life for sustainable development. Specifically, decreasing capacity utilization of major infrastructural facilities still characterizes Nigeria's economy. A major concern is that since 1999, the sub-optimality of the spending profile has consistently overlapped recurrent expenditure on capital expenditure, exacerbating the already abysmal state of infrastructure. Government expenditures range from national defence, infrastructure, grants for research, education, and the arts, and social programmes such as Social Security and Medicare. Such social programmes are not common in Nigeria and the irony is that over the years, the country's budget has neither performed nor has it allocated substantial resources to capital infrastructure on the holistic scale [19].

Expenditure on Industrial Growth in Nigeria has not been as realistic as expected for an economy that plans to be in the nearest league of twenty top industrial players. Over the past decade, manufacturing value-added as a percentage of GDP has been steadily below five percent (less than the 1960-8.6 percent independence ratio), making Nigeria one of the world's 20 least developed countries. Industrialization in Nigeria soared during the oil boom period (1973-81 with production share of GDP reaching $11 \%$ ), but fell precipitously to less than 5\% in 2013 [11].

Neighbour country for instance Ghana, have reached higher development levels in all dimensions - economic, social and environmental - for the benefit of their people. Yet, steady prosperity has not been achieved throughout Nigeria. There remain remarkable differences in the manufacturing sector between and within states across the country. Sustainable industrial development has therefore been put forward as a challenge across all parts of Nigeria.

\subsection{Research Questions}

From the above statement of research problem, the following questions emanates relating to government expenditure and sustainable industrial development in Nigeria;

1. To what extent has government revenues impacted Nigeria's industrial development?

2. To what degree has capital expenditure impacted Nigeria's industrial development?

3. To what extent has the recurrent expenditure impacted Nigeria's industrial development?

4. To determine the nexus between gross fixed capital formation and industrial development in Nigeria?

\subsection{Objectives of the Study}

The general objective of this paper states that the study investigates government expenditure and sustainable industrial development in Nigeria.

The specific objectives are;

1. To determine the impact of government revenue on industrial development in Nigeria

2. To examine the impact of capital expenditure on industrial development in Nigeria.

3. To determine the impact of recurrent expenditure on industrial development in Nigeria.

4. To evaluate the nexus between gross fixed capital formation and industrial development in Nigeria. 


\subsection{Research Hypothesis}

The following are the null and alternative hypothesis of the research study;

1. H0: Government revenue has no significant impact on industrial sector development in Nigeria.

H1: Government revenue has a significant impact on industrial sector development in Nigeria.

2. H0: Capital expenditure has no significant impact on industrial sector development in Nigeria.

H1: Capital expenditure has a significant impact on industrial sector development in Nigeria.

3. H0: Recurrent expenditure has no significant impact on industrial sector development in Nigeria.

H1: Recurrent expenditure has a significant impact on industrial sector development in Nigeria.

4. H0: Gross fixed capital formation has no significant relationship with industrial sector development in Nigeria.

H1: Gross fixed capital formation has a significant relationship with industrial sector development in Nigeria.

\subsection{Scope of study}

This research study covers the period (19812018 ) in Nigeria. The research study focus is on Nigeria and particularly the Industrial sector. Nigeria's industrial sector craves more attention to enable it to mature to an independent and self-reliant sector. Data for the study will be obtained from the CBN statistical bulletin and the WDI.

\section{Literature Review}

\subsection{Conceptual Review}

The fundamental goal of government is the economic development and improvement of the welfare of the masses. Many governments have sought to use industry as an instrument to achieve this objective. The role of the government in accelerating industrialization varies greatly according to ideology, political structures, administrative capacity and the level of development. The following are the concepts related to this study.

\subsubsection{Government Expenditure}

Government expenditure also known as public expenditure refers to the expenditure incurred by the government to maintain itself and the economy as a whole. It is the cost of the public sector to achieve specific goals. It is also a government expense incurred in carrying out its operations. Government expenditure includes recurrent expenditure associated with government running costs such as salaries, wages, the defense and maintenance of law and the order of civil and public servants, while capital expenditure involves the execution of projects such as road construction, school construction and hospital construction [4].

\subsubsection{Government Revenue}

Government revenue obtained by various departments, agencies of federal, state and local governments is referred to as administrative revenue. They include fees, licenses, fines, rates, royalties etc. [20].

\subsubsection{Gross Domestic Savings}

Savings enable capital formation and it also contributes to technological innovation and progress that helps with large-scale production processes and improves specialization, helping to boost labor productivity, resulting in increased GDP [12].

\subsubsection{Gross Fixed Capital Formation}

Gross fixed capital formation (GFCF), also known as "investment," is defined as the acquisition of generated assets (including 
second-hand asset purchases), including output by producers for their own use, minus disposals. The relevant assets relate to assets intended for use for a period of more than one year in the production of other goods and services. The phrase "generated properties" means that only those assets that arise from a production process are included. Therefore, for example, it does not include purchasing land and natural resources [15].

\subsubsection{Industrialization}

Industrialization includes policy policies in the planning and establishment of industries for job creation, poverty alleviation, income equality, etc., which in turn leads to national production growth. Industrial growth and development could be considered the heartbeat of any successful economy. The emphasis on industrial aspects of public finances in modern economic development systems stems from the fact that the industrial sector is the long-term medium for sustained growth due to the fact that the industrial sector provides the requisite leverage for competitive participation in foreign trade, expansion of domestic capacity and creation of good job opportunities [13].

Industrialization is the process of turning an economy based on extraction into an economy based on production. A nation's economic wellbeing is directly linked to its degree of industrialization and material resourcefulness, on the basis of which nations are divided into emerging, developing and developed countries [13].

\subsection{Theoretical Review}

Theoretical review looks at theories that are relevant to the variables and concepts which are in support of the independent and dependent variables. Wagner's Law (1835-1917), is used for this study.

\subsubsection{Wagner's Law}

Wagner's Law is named after the German political economist Adolph Wagner (18351917), who after empirical analysis of Western Europe at the end of the 19th century formulated a "law of the state intervention. "He argued that growth in government is a result of greater industrialization and economic development. Wagner noted that the share of public expenditure in total expenditure rises during the industrialization cycle, as a nation's real income per capita rises. The law cited that "The advent of modern industrial society would lead to increased political pressure for social reform and increased allowance by industry for social consideration" [7]. Wagner (1893) set out three focal points to increase state spending. First, public-sector activity would overtake private-sector operation during the industrialization process. State roles such as administrative and safeguard roles would increase. Second, governments have to provide cultural and social services such as education, public health, retirement or old age pension benefits, food subsidies, assistance for natural disasters, environmental conservation programs and other social functions. Third, increased industrialization would bring about technological change and a desire to monopolize large firms. Governments would have to account for these effects by supplying products of social interest and quality by budgetary means.

\subsection{Empirical Review}

In the research carried out on the effect of government spending on the Nigerian economy's growth was examined. The ex-post facto method was introduced and from the period 1980 to 2017 secondary data from the CBN statistical bulletin was used and obtained using desk survey. Among other techniques, the VAR technique was used to analyze the data. Findings showed that government capital spending had a positive but negligible impact on the Nigerian economy's growth. It was also reported that the government's fiscal deficit had a negative impact on the Nigerian economy's growth. [5]. The study on the estimated longterm and short-term trends from 1981 to 2016 between government spending and industrial development in Nigeria. The result was that government spending in Nigeria did not have a significant long-term and short-term effect on industrial development given the steady increase in government spending and various government policies to boost industrial efficiency [13]. In the study conducted on the examination of the effect of fluctuations in exchange rates and inflation on industrial output in Nigeria. The analysis covers the 
period from 1981Q1 to 2015Q4. The research followed the econometric methodology of SVAR to evaluate the effect of a shock on the output of the industry on the independent variables. Study findings show that a positive exchange rate shock has a negative impact on production growth and that a positive inflation shock has a temporary negative effect on output and after the fourth quarter is positive. The methodology of decomposition of the forecast error variance showed that the exchange rate and inflation accounted for approximately $2.6 \%$ and $10 \%$ of the fluctuations in the production of the industry respectively [18]. The empirical study investigated the complex relationship between Nigeria's non-oil revenue, government spending and economic growth from 1981 to 2015. The results also showed that, while the government spending shock was optimistic, non-oil revenue had negative shocks on economic growth. The causality of Granger showed that both non-oil revenue and economic growth from government spending granger backed the Keynesian hypothesis and spend-tax hypothesis in Nigeria. [21]. The research on Nigeria's economic growth in the industrial sector, with the premise that industrial output has no effect on Nigeria's economic growth. The research is a quantitative analysis and time series, and secondary data from 1981 to 2016 was used for the study over a 35-year period. Secondary data was used extracted from the World Bank indicators. Stata was used to analyze the results, and the results showed that industrial output had an impact on Nigeria's economic growth [1]. The research focused on the need to improve and re-strategise industrialization and industrial policy in Nigeria as a panacea for economic recovery. The result of the research was that South Korea industrialization strategy and policies began with sufficient reform of macroeconomic environment, infrastructural reforms, development of domestic machines, establishment of interdependent industries, strong reliance on domestic resources for production, special manpower training and the government unflinching aspiration to uplift the economy overshadowed every other motive which Nigerian approach could not adopt and apply [17].

\section{Methodology}

This section deals with the framework methodology. It deals with the techniques and tools used in the data collection and analysis process. The study adopts and improves on the model used by recent research work [13]. Recent works related to the variable were analyzed in this study $[2,3,5$, $9,10]$.

\subsection{Model Specification}
MVA = f (GREV, CEXP, REXP, GFCF, GDS, INFL, LINTR)

MVA = industrial growth (captured by manufacturing value added, current US\$);

GREV = government revenue; $\mathrm{CEXP}=$ capital expenditure; REXP $=$ recurrent expenditure;

GFCF $=$ Gross Fixed Capital Formation (constant 2010 US\$);

GDS $=$ Gross Domestic savings (current US\$)

INFL = Inflation, consumer prices (annual $\%)$

LINTR = Lending interest rate $(\%)$;

Note: GDS, INFL and LINTR are control variables.

Re-stating equation (1) in its Explicit and Econometric linear form, we have: $\mathrm{MVA}=\beta_{0}+\beta_{1} \mathrm{GREV}+\beta_{2} \mathrm{CEXP}+$ $\beta_{3} \mathrm{REXP}+\beta_{4} \mathrm{GFCF}+\beta_{5} G D S+$ $\beta_{6}$ INFL $+\beta_{7}$ LINTR +

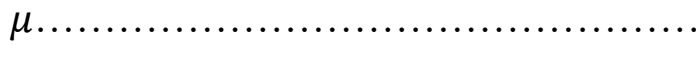

(2)

\subsection{Analysis of Data}

This involves analysis, interpretation of data and presentation of findings from the research methodology. Using unit root test, Johansen co-integration and vector correction analysis, data analysis was carried out via E-Views statistical software (version 10.0) for period between 1981 and 2018. 


\subsubsection{Unit Root Stationary Tests}

Augmented Dickey-Fuller (ADF) unit root stationarity test findings are shown below:

\section{Table 1 Unit Root Stationarity}

\section{Test}

\begin{tabular}{|l|l|l|l|}
\hline Variables & T-stat & P-value & $\begin{array}{l}\text { Order of } \\
\text { integration }\end{array}$ \\
\hline MVA & -3.608461 & .0105 & $\mathrm{I}(1)$ \\
\hline GREV & -5.655908 & .0000 & $\mathrm{I}(1)$ \\
\hline CEXP & -5.702343 & .0000 & $\mathrm{I}(1)$ \\
\hline REXP & -5.143675 & .0009 & $\mathrm{I}(1)$ \\
\hline GFCF & -3.086254 & .0369 & $\mathrm{I}(1)$ \\
\hline GDS & -3.593015 & .0112 & $\mathrm{I}(1)$ \\
\hline INFL & -6.250934 & .0000 & $\mathrm{I}(1)$ \\
\hline LINTR & -6.794232 & .0000 & $\mathrm{I}(1)$ \\
\hline
\end{tabular}

From this table, all variables are integrated of order 1, therefore, Johansen cointegration approach is the most suitable technique to be adopted.

\section{Table 2 Johansen Co-integration}

\section{test}

\begin{tabular}{|c|c|c|c|c|}
\hline $\begin{array}{l}\text { Hypoth } \\
\text { esized } \\
\text { No. of } \\
\text { CE(s) }\end{array}$ & $\begin{array}{l}\text { Eigenvalu } \\
\mathrm{e}\end{array}$ & $\begin{array}{l}\text { Trace/Max } \\
\text { Eigen Statistic }\end{array}$ & $\begin{array}{l}\text { 0.05 Critical } \\
\text { Value }\end{array}$ & $\begin{array}{l}\text { Pro } \\
\text { b.** }\end{array}$ \\
\hline None * & 0.837045 & 252.8857 & $\mathbf{1 5 9 . 5 2 9 7}$ & $\begin{array}{l}0.00 \\
00\end{array}$ \\
\hline $\begin{array}{l}\text { At most } \\
1 *\end{array}$ & 0.771636 & 189.3857 & 125.6154 & $\begin{array}{l}\text { 0.00 } \\
00\end{array}$ \\
\hline $\begin{array}{l}\text { At most } \\
2 *\end{array}$ & 0.734497 & 137.6972 & 95.75366 & $\begin{array}{l}0.00 \\
00\end{array}$ \\
\hline $\begin{array}{l}\text { At most } \\
3 *\end{array}$ & 0.666214 & 91.28269 & 69.81889 & $\begin{array}{l}0.00 \\
04\end{array}$ \\
\hline $\begin{array}{l}\text { At most } \\
4 *\end{array}$ & $\mathbf{0 . 5 7 3 4 0 0}$ & $\mathbf{5 2 . 8 7 8 7 6}$ & 47.85613 & $\begin{array}{l}0.01 \\
57\end{array}$ \\
\hline $\begin{array}{l}\text { At most } \\
5\end{array}$ & 0.309976 & 23.06193 & 29.79707 & $\begin{array}{l}0.24 \\
30\end{array}$ \\
\hline $\begin{array}{l}\text { At most } \\
6\end{array}$ & $\mathbf{0 . 2 1 5 0 3 3}$ & 10.07591 & 15.49471 & $\begin{array}{l}0.27 \\
49\end{array}$ \\
\hline $\begin{array}{l}\text { At most } \\
7\end{array}$ & 0.044738 & 1.601942 & 3.841466 & $\begin{array}{l}0.20 \\
56\end{array}$ \\
\hline \multicolumn{5}{|c|}{ Trace test indicates 5 cointegrating eqn(s) at the 0.05 level } \\
\hline None* & 0.837045 & 63.49995 & 52.36261 & $\begin{array}{l}0.00 \\
25\end{array}$ \\
\hline $\begin{array}{l}\text { At most } \\
1 *\end{array}$ & 0.771636 & 51.68847 & 46.23142 & $\begin{array}{l}0.01 \\
19\end{array}$ \\
\hline $\begin{array}{l}\text { At most } \\
2 *\end{array}$ & 0.734497 & $\begin{array}{l}46.41454 \\
\end{array}$ & 40.07757 & $\begin{array}{l}0.00 \\
85\end{array}$ \\
\hline $\begin{array}{l}\text { At most } \\
3 *\end{array}$ & 0.666214 & \begin{tabular}{|c|}
38.40393 \\
\end{tabular} & 33.87687 & $\begin{array}{l}0.01 \\
34\end{array}$ \\
\hline $\begin{array}{l}\text { At most } \\
4 *\end{array}$ & 0.573400 & 29.81684 & 27.58434 & $\begin{array}{l}0.02 \\
54\end{array}$ \\
\hline
\end{tabular}

\begin{tabular}{|l|l|l|l|l|}
\hline $\begin{array}{l}\text { At most } \\
5\end{array}$ & 0.309976 & 12.98602 & 21.13162 & \\
\hline $\begin{array}{l}\text { At most } \\
6\end{array}$ & 0.215033 & 8.473967 & 14.26460 & \\
& & & & $\begin{array}{l}0.35 \\
26\end{array}$ \\
\hline $\begin{array}{l}\text { At most } \\
7\end{array}$ & 0.044738 & 1.601942 & 3.841466 & 0.20 \\
\hline $\begin{array}{l}\text { Max-eigenvalue test indicates 5 cointegrating eqn(s) at the } 0.05 \\
\text { level }\end{array}$ \\
\hline
\end{tabular}

Trace and max-eigen helps to verify long-run relationship among these variables. For Nigeria, both trace-stat and max-eigen value shows that there are five cointegrating equations each. Due to the large sizes of the variables which are not in rates, they are logged to prevent heteroscedasticity and overly large coefficient estimates, hence, they are specified in their log-log form for the estimates of Johansen co-integration and correction of errors in vectors.

$\begin{array}{lcc}\text { Series: } & \text { LOG(MVA) } & \text { LOG(GREV) } \\ \text { LOG(CEXP) } \quad \text { LOG(REXP) } & \text { LOG(GFCF) } \\ \text { LOG(GDS) INFL LINTR } & \end{array}$

Normalized co-integration estimations:

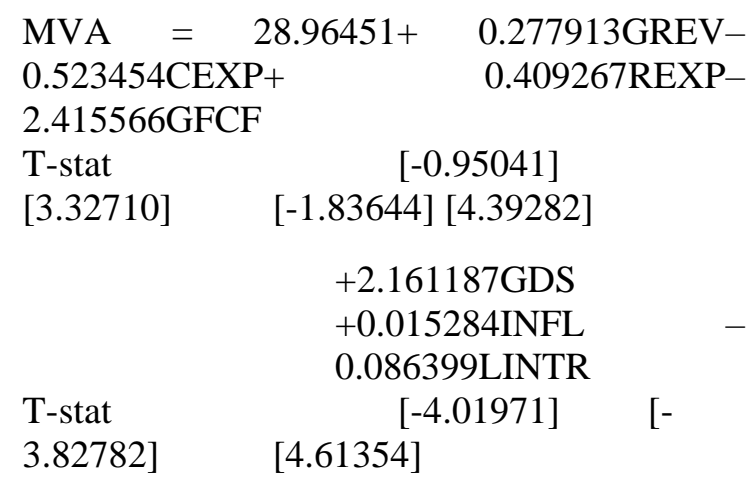

From the above, in the absence of all regressors, industrial MVA will be positive at approximately 29 units. This study finds that government revenue is statistically insignificant and a $100 \%$ change in GREV will bring about $28 \%$ changes in manufacturing output. This positive relationship conforms to theoretical expectation and indicates how Nigerian government revenue has aided industrial growth, although it is not a significant determinant. This insignificance is probably due to ineffective allocations of government revenue and late release and approval of budget proposals.

Conversely, capital expenditure significantly and negatively impacts industrial output. So, a change in CEXP will yield less than a 
proportional change in MVA by about $52 \%$. This does not conform to apriori because it is expected that greater investment in capital machineries will boost the manufacturing sector. This indicates low investment level in required equipment coupled with poorly qualified personnel to properly manage these amenities.

Conversely, recurrent expenditure positively affects industrial growth, although its influence is statistically insignificant. So, a $100 \%$ rise in REXP will cause about $41 \%$ increase in manufacturing sector's growth. This indicates that to an extent, increasing workers' wages and salaries as well as other day-to-day expenses facilitate sectoral advancement. Hence, employees should not be owed and working incentives in form of promotion and salary increment should be regularly encouraged.

A change in capital stock will lead to a significant but inelastic and less than proportional change in MVA, thereby depicting inverse relationship. This negative linkage negates apriori, thus reflecting the deficient availability of capital stock and infrastructures within the country, which translates into low level impact on industrial growth. Hence, the need for channelling revenue and capital expenditures into much more productive uses.

Meanwhile, a change in gross domestic savings will yield an elastic and more than a proportional change in manufacturing output. This significantly positive connection indicates that Nigeria's savings capacity has improved over time, probably due to more savings platform such as piggy bank, more loanfriendly financial institutes, gradual transition into cashless economy via POS and the likes. Thus, if this aggregate savings is properly transformed into investment avenues, it will have much more positive impact on Nigeria's industrial growth.

Moreover, inflation depicts a significantly positive effect as a $1 \%$ rise in inflation will engender about $1.5 \%$ increment on MVA and vice-versa. Hence, a slight increase in inflation is beneficial for industrial growth, this is because it encourages people to save and invest their money rather than squander it on unnecessary want. also, the economy will thrive especially when inflation is regulated and at fair rates. With regulated, lower inflation, this can lead to jobs rise in the economy. But unlike extreme inflationary levels which have severely harmful consequences. Furthermore, a rise in lending interest rate by banks will adversely impact manufacturing output. So, a $100 \%$ change in lending rate will induce about $8.6 \%$ change in manufacturing output. Such negative linkage aligns with theory as higher lending rate is expected to discourage lending for profitable investment ventures of manufacturing enterprises. Also, its statistical significance emphasizes the role of lending rate to industrial output.

\subsection{Vector Error Correction (VEC}

One of the preconditions for estimating autoregressive vector (VAR) model is that the time-series analysed is stationary. Economic theory, however, implies that there are equilibrium correlations in their rates of economic variables that may make these variables stationery without variations. This is, termed cointegration. Since understanding the scale of these relationships will boost the results of an analysis, in this case, it then becomes vital to provide an econometric model that can capture them. Thus, this research used the models of vector error correction (VECMs) that belong to this model class. This tests the longterm relationship \& the exogenous variable cointegrating vector.

\section{Table 3 VEC Estimates}

\begin{tabular}{|c|c|c|c|c|c|c|c|c|}
\hline $\begin{array}{l}\text { Error } \\
\text { Correc } \\
\text { tion: }\end{array}$ & $\begin{array}{l}\text { D(L } \\
\text { OG } \\
\text { (MV } \\
\text { A)) }\end{array}$ & $\begin{array}{l}\text { D(L } \\
\text { OG } \\
\text { (GR } \\
\text { EV)) }\end{array}$ & $\begin{array}{l}\mathbf{D}(\mathbf{L} \\
\text { OG } \\
\text { (CE } \\
\text { XP)) }\end{array}$ & $\begin{array}{l}\mathbf{D}(\mathbf{L} \\
\mathbf{O G} \\
(\mathbf{R E} \\
\mathbf{X P})) \\
\end{array}$ & $\begin{array}{l}\mathbf{D ( L} \\
\text { OG } \\
\text { (GF } \\
\text { CF)) }\end{array}$ & $\begin{array}{l}\text { D(LL } \\
\text { OG } \\
\text { (GD } \\
\text { S)) } \\
\end{array}$ & $\begin{array}{l}\text { D(IN } \\
\text { FL) }\end{array}$ & $\begin{array}{l}\text { D(LI } \\
\text { NTR) }\end{array}$ \\
\hline $\begin{array}{l}\text { Coint } \\
\text { Eq1 }\end{array}$ & $\begin{array}{l}0.337 \\
384 \\
\\
(0.04 \\
726) \\
{[-} \\
7.138 \\
74]\end{array}$ & $\begin{array}{l}0.047 \\
293 \\
\\
(0.12 \\
664) \\
{[--} \\
0.373 \\
45]\end{array}$ & $\begin{array}{l}0.241 \\
229 \\
\\
(0.11 \\
794) \\
{[-} \\
2.045 \\
35]\end{array}$ & $\begin{array}{l}0.099 \\
810 \\
\\
(0.08 \\
640) \\
{[} \\
1.155 \\
15]\end{array}$ & $\begin{array}{l}0.266 \\
643 \\
\\
(0.04 \\
663) \\
{[-} \\
5.718 \\
46]\end{array}$ & $\begin{array}{l}0.203 \\
762 \\
\\
(0.09 \\
977) \\
{[-} \\
2.042 \\
33]\end{array}$ & $\begin{array}{l}6.576 \\
734 \\
\\
(5.65 \\
850) \\
{[} \\
1.162 \\
27]\end{array}$ & $\begin{array}{l}2.898 \\
585 \\
\\
(0.901 \\
47) \\
{[} \\
3.215 \\
41]\end{array}$ \\
\hline 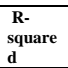 & $\begin{array}{l}0.728 \\
143\end{array}$ & $\begin{array}{l}0.254 \\
342\end{array}$ & $\begin{array}{l}0.339 \\
493\end{array}$ & $\begin{array}{l}0.423 \\
605\end{array}$ & $\begin{array}{l}0.735 \\
474\end{array}$ & $\begin{array}{l}0.454 \\
568\end{array}$ & $\begin{array}{l}0.303 \\
006\end{array}$ & $\begin{array}{l}0.571 \\
820\end{array}$ \\
\hline $\begin{array}{l}\text { Adj. } \\
\text { R- } \\
\text { square } \\
\text { d }\end{array}$ & $\begin{array}{l}\mathbf{0 . 6 3 0} \\
275\end{array}$ & $\begin{array}{l}0.014 \\
094\end{array}$ & $\begin{array}{l}0.101 \\
711\end{array}$ & $\begin{array}{l}0.216 \\
102\end{array}$ & $\begin{array}{l}0.640 \\
245\end{array}$ & $\begin{array}{l}0.258 \\
213\end{array}$ & $\begin{array}{l}0.052 \\
088\end{array}$ & $\begin{array}{l}0.417 \\
675\end{array}$ \\
\hline
\end{tabular}

From the error correction test above, ECM reveals a negative figure of -0.337 , this suggests convergence of errors, and hence, about $34 \%$ percent of errors that occur in the short run will be corrected subsequently in the long run. Moreover, $\mathrm{R}^{2}$ and adjusted $\mathrm{R}^{2}$ depict that all explanatory variables jointly explain about $73 \%$ and $63 \%$ respectively of variations in 
manufacturing output (industrial growth) in Nigeria.

\section{Discussion of findings}

\subsection{Statistical Analysis of the Three Hypothesis}

The four hypotheses formulated in this study were tested using student t-statistics. The level of significance for the study is $5 \%$, for a two tailed test. The decision rule is that we shall accept the null hypothesis if the critical/t-value $( \pm 2)$ is greater than the calculated value, otherwise reject the null hypothesis. That is, using the student $t$-test ( $t$-statistic), we say that a variable is statistically significant if $t^{*}(t-$ calculated) is greater than the tabulated value of \pm 2 under $95 \%$ (or 5\%) confidence levels and it is statistically insignificant if the $t^{*}$ is less than the tabulated value of \pm 2 under $95 \%$ (or $5 \%$ ) confidence levels. Thus;

$$
\begin{aligned}
& \mathbf{H}_{\mathbf{0}} \text { : Null hypothesis } \beta_{0}=0 \\
& \mathbf{H}_{\mathbf{1}} \text { : Alternative hypothesis } \beta_{1} \neq 0
\end{aligned}
$$

\section{Hypothesis one:}

$\mathrm{H}_{0}$ : Government revenue has no significant impact on industrial sector development in Nigeria.

The calculated t-value for GREV is +0.9504 from the regression result and the tabulated value is \pm 2 . Since the calculated t-value is less than the tabulated / critical value (i.e., $0.9304<$ \pm 2 ), it, therefore, lies within the region of acceptance and we, therefore, accept the null hypothesis. Thus concluding, that government revenue (GREV) has no significant impact on industrial sector in Nigeria.

The parameter estimates of government revenue showed that it relates positively with MVA but is, considered statistically insignificant. This positive relationship showed that the higher the government revenue, the higher the development of Nigeria's industrial sector. The result, therefore, showed that a percentage change in GREV (holding other variables constant), on the average, increased the MVA of Nigeria by 0.2779 per cent

\section{Hypothesis two:}

$\mathrm{H}_{0}$ : Capital-expenditure has no significant impact on industrial. sector. development in Nigeria.

The calculated t-value for CEXP is 3.3271 from the regression test, \& the critical/tabulated-value is \pm 2 . Since, the calculated t-value is greater than the tabulated t-value (i.e. 3.3271- > \pm 2 ), it thus falls in the rejection region of, and therefore we reject the null $(H O)$ hypothesis and accept the alternate hypothesis. The inference is that capital expenditure (CEXP) has a significant impact on industrial sector development in Nigeria.

Furthermore, the CEXP parameter estimates show that it relates negatively to MVA and was found to have statistical influence on MVA. This does not conform to apriori because it is expected that greater investment in capital machineries will boost the manufacturing sector. The negative relationship shows that the lower the CEXP, the lower the development of Nigeria's industrial sector (MVA). Concluding, therefore, that a change in percentage of CEXP (holding constant other variables), on the average, decreased the MVA of Nigeria by 0.5234 per cent.

\section{Hypothesis three:}

$\mathrm{H}_{0}$ : Recurrent expenditure has no significant impact on industrial sector development in Nigeria

From the regression result, the calculated tvalue for REXP is -1.8364 and the tabulated value is \pm 2 . Since the calculated $t$-value is less than the tabulated t-value (that is, $-1.8364<$ \pm 2 ), it, therefore, falls in the acceptance region and hence, we accept the null hypothesis. The conclusion is that recurrent expenditure (REXP) has no significant impact on the industrial sector development in Nigeria.

The parameter estimates of the REXP showed it has a positive and insignificant relationship with MVA. A positive relationship negates apriori expectations. It shows that the government of Nigeria is spending more money on supposed wages and salaries, as well as other day-to-day expenses, which does not necessarily facilitate sectoral advancement and definitely not the development of Nigeria's 
industrial sector (MVA). The result, therefore, showed that a percentage change in REXP (holding other variables constant), on the average, increased the MVA of Nigeria by 0.4090 per cen.

\section{Hypothesis four:}

$\mathrm{H}_{0}$ : Gross fixed capital formation has no significant relationship with industrial sector development in Nigeria.

The calculated t-value for GFCF is 4.3292 from the regression result and the tabulated value is \pm 2 . Since, the calculated t-value is greater than the tabulated t-value (i.e., 4.39282 $> \pm 2$ ), it thus falls into the rejection region. Therefore, we reject the null (H0) hypothesis. The inference is that the Gross fixed capital formation (GFCF) has a significant relationship with industrial sector development in Nigeria. The parameter estimates of the GFCF however, shows that it has an inverse relationship with, MVA. A negative relationship connotes that a change in capital stock (GFCF) will lead to a significant but inelastic and less than proportional change in MVA, thereby depicting inverse relationship. This negative linkage negates apriori, thus reflecting the deficient availability of capital stock and infrastructures and income inequality within the country, which translates into low-level productivity in the development of Nigeria's industrial sector.

\section{Conclusion}

The urgency and role of government spending in the Nigerian economy's development, particularly in terms of industrial growth, has been directed towards a very short-term imperative that involves fiscal deficits through a mixture of reduced revenue and higher spending. The long-term issue that has the capacity for change that can be achieved in ways that promote growth rather than inhibit it has been negated. The quality of government expenditure relies on the efficacy of federal, state, and local governments in their constituent parts. By Efficacy of Government, it implies, Government Effectiveness Indicator. This indicator measures the quality of public services, the quality of the civil service and its independence from political pressures, the quality of policy formulation and implementation, and the credibility of the government's commitment to its stated policies. it is also the citizens' faith and trust in government and their belief that they can understand and influence political affairs. A combination of excessive federal government power, inadequate oversight of autonomous departments, and ambiguous budgetary relationships between the different parts of government has often led to inefficient mobilization and use of public funds in areas such as the industrial sector where it is most relevant. This is because the advancement of a country is directly related to the level of industrial sector development. The industrial sector creates job possibilities, offers incentives for jobs, promotes development and creativity, and allows better use of capital. All these advantages and more make industrial sector development of great value to the population and to the Nigeria economy. This study contributed empirically and conceptual to government expenditure discussions.

\subsection{Recommendation}

The following recommendations are based on the analysis and findings;

1. The insignificance of government revenue represents the pragmatic approach in the industrial sector allocations. The view of public finance emphasizes the potential benefits of government intervention when applied successfully to address market failures. Therefore, if this approach transitions to a more transparent one where proper control and balance are in place, this will go a long way towards improving the industry's performance.

2. Industrial policies in time past has failed for example the Industrial Park Development Strategy (IPDS) 2009 failed despite bureaucratic deficiencies in the provision of basic physical services in industrial park areas. If all these political misconducts are eliminated the will be massive development of the industrial sector.

3. The negative impact of capital expenditure reflects the low investment level, which means the need for more 
sustainable investment level in the training of skilled human capital staff as well as the procurement and maintenance of equipment.

4. Whatever policies or incentives government implements, it should ensure that it enhances the capacity of people to save that can turn into an investment avenue.

5. Finally, the lending rate should be sufficiently small not to push away local and foreign investors.

\section{Author's Contribution}

1. ALEXANDER

EHIMARE

OMANKHANLEN; SUPERVISION

2. PEACE ONYEDIKACHI CHIMEZIE;
WRITING-ORIGINAL DRAFT,
CONCEPTUALIZATION,
METHODOLOGY REVIEW \& EDITING

3. LAWRENCE UCHENNA OKOYE; PROJECT ADMINISTRATION

\section{Acknowledgements}

We want to acknowledge Covenant University Centre for Research, Innovation and Development (CUCRID) for providing an enabling environment for this research

\section{Reference}

[1] Abdu, M., \& Anam, B. E. (2018). Evaluation of the Nigerian Industrial sector and Economic Growth in the face of Sustainable Development. International Journal of Advanced Research in Public Policy, Social Development and Enterprise Studies, 3 (1), 4959.

[2] Adebayo, F. A., Adebisi, A. T., \& Mamidu, I. A. (2014). An Econometric Analysis of Impact of Public Expenditure on Industrial Growth in Nigeria. International Journal of Economics and Finance, 6 (10), 112-117.

[3]. Aganga, O. O. (2014). Nigeria Industrial Revolution Plan. Retrieved October 25, 2019, from Bank of Industry: https://www.boi.ng
[4] Ajibola, R. (2008). Public Finance Principles and Practice (2nd Edition ed.). Ifako, Lagos, Lagos, Nigeria: AVL publishing.

[5] Anthony, O., Eyo, I. E., \& Arikpo, F. O. (2019). Public Expenditure and Economic Growth in Nigeria: VAR APPROACH. European Journal of Economics and Financial Research, 3 (3), 36-59.

[6] Barrios, S., \& Andrea, S. (2008). Directorate-General Economic and Financial Affairs. Retrieved July 7, 2019.

[7] Bastable, C. F. (1892). Journal of Political Economy. University of Chicago Press Journals, 1 (1), 133-142.

[8] Ekpo, U. N. (2014). Nigeria Industrial Policies and Industrial Sector Performance: Analytical Exploration. International Journal of Economics and Finance, 3 (4), 01-11.

[9] Ejaz, Z., Ullah, M. A., \& Khan, M. U. (2019). Determinants of Industrial Growth in South Asia: Evidence from Panel Data Analysis. Papers and Proceedings pp. 97110

[10] Falaye, A. J., Oluwasegun, E., Adegbola, O., Asamu, F., Ogunlade, P., Egbide, B.-C., et al (2019). Impact of Exchange Rate on the Manufacturing Sector in Nigeria. International Journal of Mechanical Engineering and Technology, 10 (2), 1568-1583.

[11] Iweriebor, S., Eghareuba, M. I., \& Abidemi, A. C. (2015). Government Spending and Industrial Development in Nigeria: A dynamic Investigation. Annals of the University of Petrosani, Economics, 15 (1), 179-190.

[12] Jagadeesh, D. (2015). Impact of Savings in Economic Growth: An Empirical Study Based on Botswana. International Journal of Research in Business Studies and Management, 2 (9), 10-21. 
[13] Jeff-Anyeneh, S. E., Ezu, G. K., \& Ananwude, A. C. (2019). Government Expenditure and Industrial development in Nigeria: Longrun and Shortrun Dynamics from ARDL Approach. Journal of Scientific Research and Reports, 23 (6), 19.

[14] Kamiguchi, A., \& Toshiki, T. (2019). Public investment, public debt and population aging under the golden rule of public finance. Journal of Macroeconomics, 110-122.

[15] Lucky, A.L., \& Uzah, C.K. (2016). Determinants of Capital Formation in Nigeria: A Test of Jhingan's Preposition 1981-2014.International Journal of Banking and Finance Research, 2(1), 1-19. ISSN 2695-186X

[16] Noko, E. J. (2016). Impact of Industrial Sector on Nigeria Economy Growth. Retrieved October 25, 2019, from Educacinfo: https://educacinfo.com

[17] Ogbonna, B., \& Uma, K. E. (2017). Re-strategising Nigeria's Industrialisation and Industrial Policy for Economy Recovery: Lessons from South Korea. International Journal of Rrsearch in Management, Economics and Commerce, 7 (7), 88-97.

[18] Okafor, T. C., Babajide, A. A., \& Adebgite, E. O. (2018). Exchange Rate
Flunctuations, Inflation and Industrial Output in Nigeria. 31st IBIMA Conference (pp. 25-36). Milan, Italy: Scopus.

[19] Okorafor, I. A., \& Uwatt, U. B. (2019). Editorial Advisory Committee. 43(1), 66. Promoting inclusive and sustainable industrialization | United Nations. (n.d.). Retrieved 15 March 2020.

[20] Ola, R. O., \& Offiong, J. O. (1999). Public Financial Management (1st Edition ed.). (M. O. Basil Jomoh, Ed.) Apapa, Lagos, Nigeria: AMFITOP BOOKS.

[21] Olayungbo, D. O., \& Olayemi, O. F. (2018). Dynamic relationship among nonoil revenue, government spending and economic growth in an oil-producing country: Evidence from Nigeria. Future Business Journal, 246-260.

[22] United Nations Industrial Development Organization. (2018). Industrial Development Report 2018: Demand for Manufacturing - Driving Inclusive and Sustainable Industrial Development. UN. https://doi.org/10.18356/b0cad365-e

[23]. World Bank national accounts data, a. O. (2016). Nigeria - Manufacturing, value added (\% of GDP). Retrieved November 11, 2019, from Indexmundi: https://www.indexmundi.com

\section{Creative Commons Attribution License 4.0 (Attribution 4.0 International, CC BY 4.0)}

This article is published under the terms of the Creative Commons Attribution License 4.0

https://creativecommons.org/licenses/by/4.0/deed.en US 